\title{
PERBAIKAN PERTUMBUHAN IKAN NILA (Oreochromis niloticus) DENGAN SELEKSI FAMILI
}

\author{
Rudhy Gustiano*), Otong Zenal Arifin*), dan Estu Nugroho*) \\ *) Balai Riset Perikanan Budidaya Air Tawar, Bogor
}

\begin{abstract}
ABSTRAK
Dewasa ini ikan nila merupakan salah satu ikan ekonomis penting di dunia yang dikenal sebagai freshwater chicken. Di Indonesia ikan nila telah dibudidayakan secara luas. Namun demikian kesediaan benih unggul dengan pertumbuhan cepat yang menguntungkan usaha budidaya nila masih merupakan kendala utama. Berdasarkan latar belakang ini, perbaikan mutu genetik nila untuk meningkatkan produksi dan produktivitas di masa mendatang sangat dibutuhkan. Dalam makalah ini akan diuraikan status, upaya, hasil riset pemuliaan, dan selective breeding yang telah dan sedang dilakukan di Indonesia dalam rangka untuk meningkatkan produksi dan produktivitasikan nila nasional. Hasil yang diperoleh dari kegiatan selective breeding ikan nila "Balitkanwar" melalui seleksi famili diperoleh jenis unggulan yang baik keragaannya dari berbagai aspek yang diuji. Keragaan ikan nila "Balitkanwar" secara mendetail akan disampaikan dalam makalah ini.
\end{abstract}

KATA KUNCl: pertumbuhan, seleksi, genetika, ikan nila, Oreochromis niloticus

\section{PENDAHULUAN}

Ikan nila di Indonesia merupakan ikan ekonomis penting di dunia karena cara budidaya yang mudah, rasa yang digemari, harga relatif terjangkau, dan memiliki toleransi yang luas terhadap lingkungan. Dewasa ini, ikan nila dipelihara secara komersial berbagai belahan dunia baik di kolam atau keramba jaring apung (KJA) di air payau maupun air tawar serta perairan pantai. Disebabkan oleh minat masyarakat yang semakin meningkat, ikan nila ini menjadi komoditi yang menarik, baik dalam usaha budidaya skala besar maupun skala kecil.

Di Indonesia, ikan nila merupakan jenis ikan introduksi yang didatangkan ke Bogor pada tahun 1969 dari Taiwan. Sejak nila diintroduksi ke Indonesia pada tahun 1969, perkembangan budidayanya di masyarakat cukup pesat.
Sekarang jenis ikan ini sudah dibudidayakan di 32 provinsi di Indonesia (Anonim, 2006). Produksi nila pada tahun 1996 tercatat sebesar 25.668 ton dan menjadi 148.249 ton pada tahun 2005. Dengan demikian telah terjadi peningkatan sebesar $578 \%$ dalam kurun waktu 9 tahun (Anonim, 2006). Terlebih lagi dengan adanya kasus KHV (koi herpes virus) pada ikan mas, nila menjadi alternatif ikan air tawar yang dibudidayakan masyarakat dan menjadi salah satu andalan dalam program revitalisasi perikanan.

Di pasar internasional Amerika Utara (Amerika Serikat dan Canada) serta Eropa, dari tahun ke tahun konsumsi ikan nila semakin meningkat (Fish Farming Intl., 2005; 2006). Amerika Utara mengimpor 112.945 ton pada tahun 2004, meningkat 25\%dari tahun 2003 atau 68\%lebih tinggi dibandingkan tahun 2002. Di mana nilai impornya juga meningkat sampai \$297 juta tahun 2004, 23\%lebih tinggi dari tahun 2003, dan 71\%dari tahun 2002 (Fish Farming Intl., 2005). Setengah dari impor Amerika Utara dipasok oleh China, sedangkan sisanya oleh Taiwan, Thailand, dan Indonesia. USDA (United State Department of Agriculture) memberikan dukungan agar ketiga negara pengekspor utama dapat mengambil alih porsi impor yang dikuasai oleh China. Hal ini merupakan peluang yang harus disikapi secara positif. Patut diperhitungkan bahwa budidaya ikan nila telah mulai menarik perhatian negara-negara Amerika Selatan yang dapat menjadi pesaing handal karena transportasi yang lebih murah. Oleh karena itu penting sekali diupayakan budidaya yang efisien.

Upaya peningkatan produksi ikan nila terus dilakukan dengan berbagai cara seperti mendatangkan beberapa strain unggul baru dari luar, perbaikan teknologi perbenihan dan budidaya, serta perbaikan genetik. Perbaikan perbenihan dan budidaya dilakukan dengan menggunakan teknologi maju, seperti penggunaan corong penetasan untuk perbenihan dan resirkulasi pada budidaya sistem tertutup, serta rekayasa wadah budidaya yang semakin maju. Untuk upaya perbaikan genetik antara lain dilakukan dengan menghasilkan jenis nila "monosex", rekayasa genetik, dan seleksi secara konvensional untuk menghasilkan strain ikan nila dengan tampilan yang spesifik (Wardoyo, 2005; Gustiano, 2007). 
Berdasarkan latar belakang di atas dapat dikemukakan arti penting nila bagi budidaya air tawar. Oleh karena itu, dukungan pengembangan teknologi budidaya dan perbaikan mutu genetik nila untuk meningkatkan produksi dan produktivitas di masa mendatang sangat dibutuhkan. Dalam makalah ini akan diuraikan perbaikan yang telah dan sedang dilakukan di Indonesia dalam rangka meningkatkan produksi dan produktivitas ikan nila nasional.

\section{STATUS PEMULIAAN IKAN NILA}

Dalam periode waktu yang cukup lama, konsentrasi perikanan nila nasional bertitik berat pada optimalisasi teknik dan sistem budidaya serta penyediaan benih bagi budidaya untuk meningkatkan produksi. Sedangkan pengembangan mutu genetik komoditas dirasakan masih tertinggal. Sejak nila diintroduksi dari Taiwan 1969, upaya perbaikan mutu genetik hanya dilakukan dengan cara mendatangkan strain unggul dari luar. Khusus nila berwarna hitam, jenis-jenis dari luar negeri didatangkan dari Thailand tahun 1989 (Chitralada), Filipina tahun 1994, dan 1997 (GIFT). Sedangkan jenis warna merah didatangkan dari Thailand tahun 1989 (NIFI). Namun beberapa tahun terakhir terjadi kecenderungan penurunan kualitas genetik karena kurang tepatnya pengelolaan yang berpengaruh terhadap laju pertumbuhan (Gustiano et al., 2007). Hasil akhir dari penurunan pertumbuhan tersebut menyebabkan penurunan produksi dan produktivitas, serta pendapatan pembudidaya ikan.

Di Indonesia, penelitian dasar terhadap perbaikan mutu genetik nila telah dilakukan oleh banyak peneliti terdahulu (Brzesky \& Doyle, 1988; Matricia et al., 1989; Jangkaru et al., 1992; Widiyati et al., 1996, 2006; Widiyati, 2003; Ariyanto \& Imron, 2002; Nugroho et al., 2002; Wakhid \& Suwarsito, 2003). Meskipun demikian penelitian-penelitian tersebut belum dalam konteks breeding program yang besar, masih berjalan sendirisendiri dan terputus. Dengan tersedianya 'road map' arah penelitian harus saling mendukung dan produksi ikan unggul dapat diraih di masa mendatang dapat lebih efektif dan efisien. Untuk mencapai produksi unggulan, seluruh pihak yang berkepentingan hendaknya dapat bekerja sama untuk satu tujuan yang berskala nasional. Dalam hal tersebut, peranan pengambil kebijakan dan dukungan industri perikanan sangat dibutuhkan untuk menunjang kesinambungan program dan produksi ikan nila unggul yang berkelanjutan.

\section{UPAYA PEMULIAAN IKAN NILA}

Perbaikan mutu genetik untuk meningkatkan produksi dan produktivitas pada ikan nila dapat dilakukan dengan berbagai cara.
Pertama dengan melakukan introduksi jenis unggul dari luar sebagai material dasar/genetik untuk memperbaiki keragaan ikan lokal dan menggunakannya (Gustiano et al., 2006). Kerugian yang muncul akibat introduksi dapat menyebabkan pencemaran genetik melalui interaksi antara jenis asli dan pendatang akibat adanya penyisipan gen (introgresi) pada ikan asli. Pencemaran genetik dapat berlanjut sampai mengakibatkan terjadinya penggantian/kepunahan spesies asli dengan spesies pendatang atau penurunan mutu genetik dari ikan introduksi. Contoh adalah kasus pada nila introduksi GIFT dari Filipina yang memberikan dampak besar terhadap jenis yang telah lama ada di Indonesia.

Kedua dengan melakukan persilangan/hibridisasi untuk mendapatkan sifat unggul yang lebih baik dari populasi asal. Pada dasarnya, hibridisasi adalah memanfaatkan sifat heterosis karena sifat dominan dan heterozigot pada banyak lokus (Tave, 1993) atau interaksi dari alela pada lokus (Kapuskinski, 1986). Persilangan umumnya dilakukan antar populasi yang memiliki keunggulan spesifik. Kegiatan persilangan pada nila di Indonesia banyak dilakukan oleh para pembudidaya untuk mendapatkan jenis yang memiliki pertumbuhan lebih cepat atau tampilan tertentu. Produk hibrida banyak ditemui di masyarakat. Namun demikian, apabila persilangan dilakukan secara tak terkendali akan mengakibatkan hilangnya sifat/karakter spesifik dari populasi asal. Untuk menghindari hal yang tidak dikehendaki sebaiknya hasil persilangan/hibrida hanya digunakan sebagai produk akhir saja untuk konsumsi.

Ketiga dengan memanfaatkan keunggulan jenis kelamin jantan (Dunham et al., 2001). Pada nila telah diketahui umum bahwa jenis jantan memiliki pertumbuhan dua kali lipat dibandingkan dengan betina (Tave, 1995; Gustiano et al., 2006). Pembentukan jenis jantan dapat dilakukan sebagai berikut: 1) pemberian hormon melalui pakan atau perendaman (Zairin, 2003), 2) rekayasa genom/androgenesis dengan cara merusak sifat betina dan ditindaklanjuti dengan diploidisasi secara buatan (Myer et al., 1995; Sugama, 2006), 3) pembentukan pejantan super (YY supermale) (Scott et al., 1989; Mair et al., 1995; Arifin et al., 2004).

Keempat dengan melakukan seleksi terhadap karakter penting. Seleksi merupakan suatu teknik untuk memperbaiki sifat yang terukur (quantitative trait). Prinsip dasar dari seleksi adalah mengekploitasi sifat 'additive' dari alela-alela pada semua lokus yang mengontrol sifat terukur untuk memperbaiki suatu populasi (Kirpichnikov, 1980; Fal coner, 1989; Tave, 1993; Gjedrem, 2005). Secara mendasar seleksi dapat dibedakan menjadi seleksi 
individu/massa dan famili. Pada seleksi individu hubungan kekerabatan diabaikan dan uji banding dilakukan di antara individu. Individu-individu diurutkan berdasarkan kriteria/ ukuran dan yang terbaik akan diambil sebagai calon induk. Sedangkan pada seleksi famili, hubungan famili merupakan faktor yang penting dan rata-rata famili dibandingkan untuk mengambil keputusan selanjutnya. Dalam seleksi famili pengambilan keputusan dapat dikelompokkan menjadi "antar famili/between family atau dalam famili/within family". Gabungan antara antar dan dalam famili disebut kombinasi antar dan dalam famili. Jenis seleksi lainnya (tandem, independent culling, dan selection index) merupakan variasi dari kedua bentuk seleksi tersebut (Kapuskinski, 1986; Tave, 1995; Gjedrem, 2005).

Kelima dengan DNA recombinant/"gene transfer"/ "transgenic". Teknik ini merupakan persilangan pada tingkatan molekuler. Untuk melakukan transfer gen dibutuhkan 'DNA construct' yang terdiri atas 'transgene' dan 'promoter' sebagai bahan dasar yang akan ditransfer ke ikan target. Pembentukan ikan transgenik melalui transfer 'DNA construct' dapat dilakukan dengan beberapa metode yaitu: 1) microinjection, 2) electroporation, 3) spermmediated transfer, 4) biolistics, 5) viral vectors, dan 6) lipofection (Beaumont \& Hoare, 2003). Transgenik pada nila pertama kali dilakukan oleh Rahman \& MacClean (1999). Hasil yang diperoleh memperlihatkan bahwa jenis transgenik memiliki pertumbuhan 300\% lebih besar dibandingkan dengan nontransgenik. Martinez et al. (1999) juga melaporkan keunggulan pertumbuhan ikan transgenik dengan perbedaan yang sangat nyata.

\section{RISET DAN HASIL PEMULIAAN IKAN NILA}

Nila merupakan salah satu ikan introduksi yang memegang peranan penting pada budidaya air tawar. Estimasi dari produksi ikan introduksi di Asia mencapai 12\%dari produksi budidaya (2,6 ton) (De Silva et al., 2006). Jumlah tersebut akan meningkat menjadi lebih dari $40 \%$ apabila Cina tidak dimasukkan dalam perhitungan. Untuk Indonesia produksi perikanan budidayanya hampir sebagian besar dihasilkan oleh jenis introduksi (Gustiano et al., 2006). Namun demikian, belum banyak riset yang memantau sejauh mana pengaruh peningkatan mutu genetik yang diberikan ikan dari luar terhadap ikan lokal. Fenomena umum yang ada adalah terjadinya penurunan keunggulan ikan introduksi sejalan dengan waktu akibat pengelolaan yang tidak tepat. Kasus ini banyak terjadi pada ikan nila yang didatangkan ke Indonesia.

Publikasi ilmiah persilangan pada nila di Indonesia tidak banyak ditemui. Tercatat hasil persilangan dengan hasil hibrida yang lebih baik antara ikan nila (Oreochromis niloticus) dan mujair (Tilapia mosambicus) (Sumanta- dinata \& Subardja, 1979; Suseno, 1983) dan antar strain ikan nila (Yunus et al., 1987). Kenyataan yang ada memperlihatkan bahwa kegiatan persilangan pada nila di Indonesia banyak dilakukan oleh para pembudidaya. Para pembudidaya melakukan persilangan karena nila sangat mudah dikembangbiakkan untuk mendapatkan jenis yang memiliki pertumbuhan lebih cepat atau tampilan tertentu. Hibrida-hibrida banyak ditemui di masyarakat dengan nama lokal yang terkadang sulit ditelusuri asal usulnya. Riset pengalihan kelamin jantan telah banyak dilakukan di Indonesia dengan berbagai jenis hormon dan metode pemberiannya (Subagyo et al., 1993; Widiyati et al., 2005). Pertumbuhan bobot mutlak ratarata pada pemeliharaan tunggal kelamin jantan lebih besar 17,7\%dibandingkan dengan ikan campur kelamin. Jangkaru et al. (1988) melaporkan hasil yang lebih baik pada pemeliharaan tunggal kelamin di kolam tanah. Menurut Widiyati et al. (2005), rata-rata produksi pada pemeliharaan tunggal kelamin 51,5\% lebih besar dibandingkan dengan pemeliharaan campur kelamin. Sedangkan riset 'yy super male' telah menghasilkan jenis 'GESIT' (genetically supermale tilapia) yang telah dilepas secara resmi (Anonim, 2006).

Seleksi merupakan salah satu kegiatan riset yang banyak dilakukan, hanya patut disayangkan banyak kegiatan tidak berkelanjutan. Dalam konteks 'breeding program' seleksi individu dan famili mulai dilakukan di berbagai institusi. Hasil yang telah diperoleh dari program seleksi famili adalah berupa jenis 'Nirwana' dari Wanayasa yang memiliki 'genetic gain' 12,8\%untuk betina dan 30,4\% untuk jantan pada F2 (Anonim, 2006).

Untuk riset transgenik, kegiatan ini masih dalam tahap persiapan sarana dan sumber daya manusia. Sedianya kegiatan akan dilakukan dalam waktu dekat melalui kerja sama antar unit pelaksana teknis Departemen Kelautan dan Perikanan dengan institusi terkait.

\section{SELECTIVE BREEDING PADA IKAN NILA}

Secara umum gambaran riset genetika dalam budidaya perikanan dapat dilihat pada Gambar 1. Dari berbagai jenis riset genetika yang dilakukan, selective breeding masih merupakan salah satu yang dominan. Berdasarkan sifat yang ingin diperbaiki pada program seleksi, perbaikan pertumbuhan merupakan sasaran yang paling utama (Gambar 2). Melihat jenis spesies target riset genetik pada budidaya perikanan, ikan nila (Gambar 3) memiliki persentase yang cukup tinggi (Gambar 4). Di Balai Riset Perikanan Budidaya Air Tawar, penelitian selective breeding ikan nila telah dilakukan untuk memperbaiki pertumbuhan populasi ikan nila yang ada. Langkah-langkah yang ditempuh akan disajikan di bawah ini. 


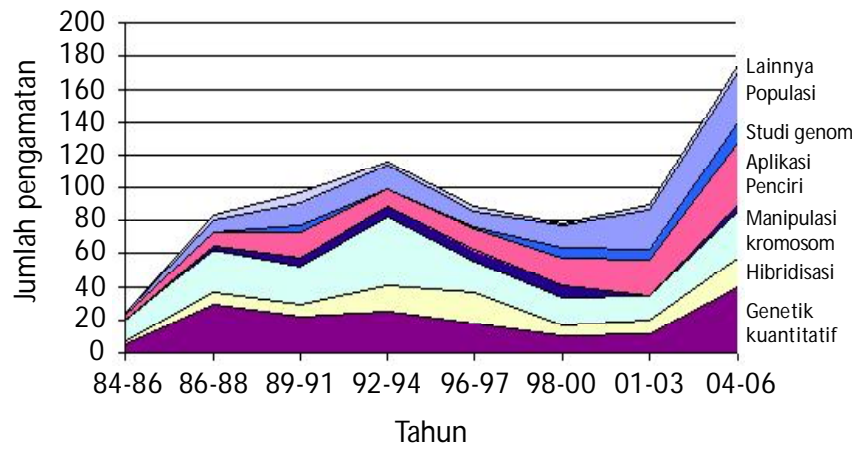

Gambar 1. Trend riset genetika pada budidaya perikanan

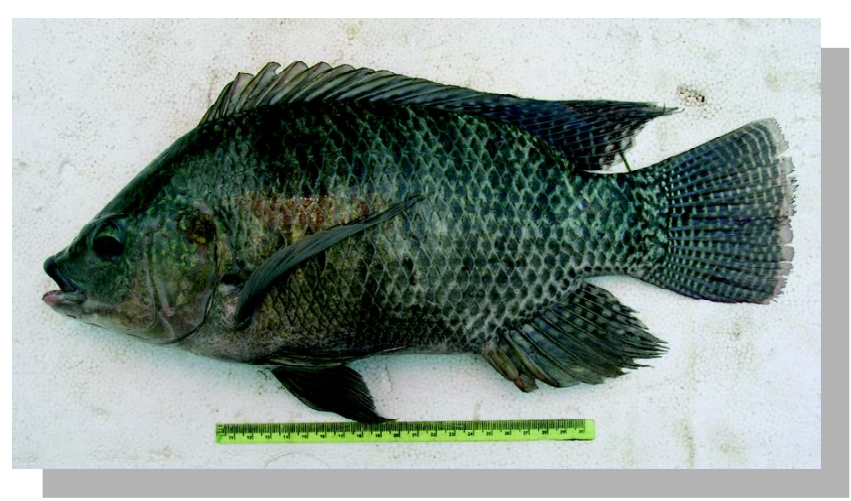

Gambar 3. Ikan nila (Oreochromis niloticus)

\section{Karakterisasi keragamanan genetik}

Keragaman genetik beberapa ras ikan nila yang digunakan dalam budidaya telah diteliti dengan menggunakan polimorfisme mitokondria DNA D-loop (Nugroho et al., 2002). Hasil yang diperoleh memperlihatkan adanya enam komposisi haplotipe terdeteksi dengan menggunakan tiga enzim restriksi (M bol, Haelll, dan Hinfl).

Jarak genetik rata-rata antar populasi ikan nila adalah sekitar 0,0178. Dendrogram yang dibentuk berdasarkan jarak genetik tersebut menunjukkan bahwa koleksi nila dari Sukamandi, Sukabumi, dan Jatiluhur mempunyai kekerabatan yang relatif lebih dekat dibandingkan dengan kekerabatan antara ketiganya dengan ikan nila dari Danau Tempe atau Cirata (Gambar 5).

\section{Evaluasi pertumbuhan populasi}

Empat populasi ikan nila (GIFT 6, GIFT 3, lokal, dan Danau Tempe) telah diuji keragaan pertumbuhannya menggunakan ikan ukuran rata-rata $4,7 \mathrm{~cm}$ di Instalasi Plasma Nutfah Cijeruk (Gustiano et al., 2005). Hasil yang diperoleh memperlihatkan tidak adanya perbedaan untuk parameter biomassa selama empat bulan pengamatan.

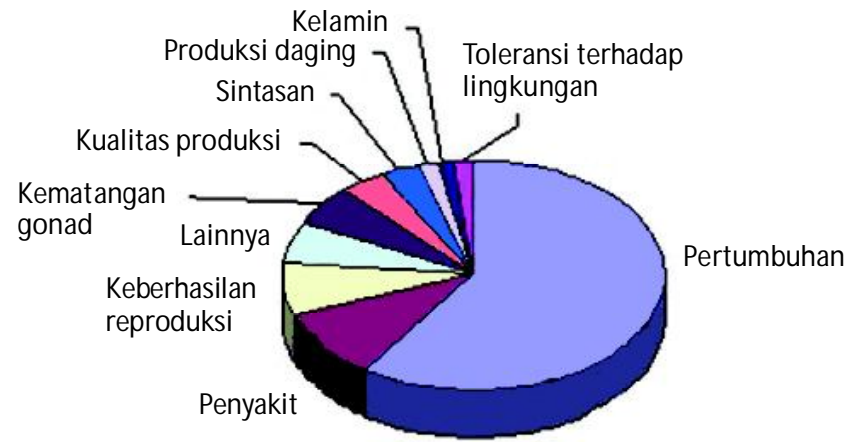

Gambar 2. Fokus sasaran riset seleksi pada budidaya perikanan

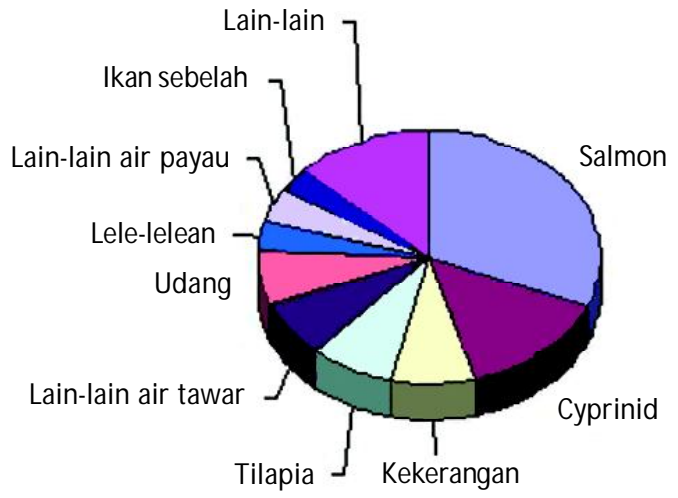

Gambar 4. Pola target spesies riset genetika pada budidaya perikanan

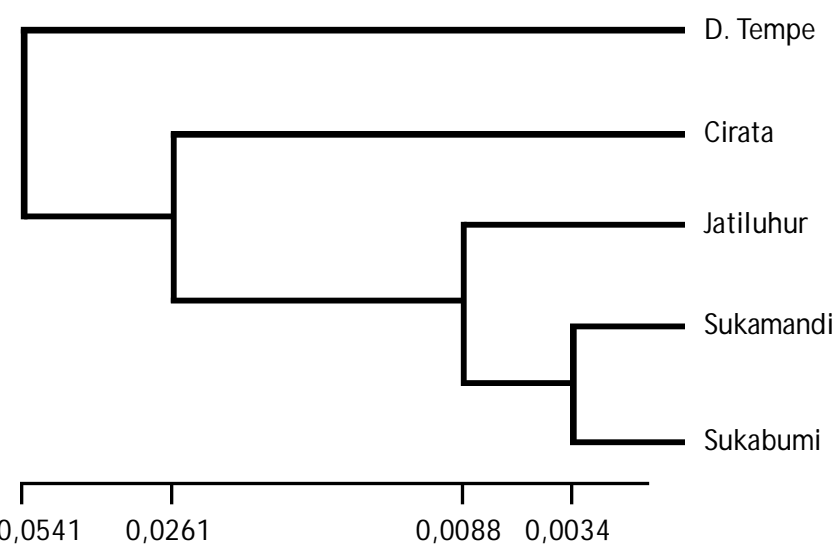

Gambar 5. UPGMA dendrogram dari beberapa koleksi ikan nila GIFT dan Danau Tempe (Nugroho et al., 2002)

Sedangkan untuk pertumbuhan panjang individu terdapat perbedaan yang sangat nyata $(P<0,01)$ dari empat populasi yang diamati (Gambar 6).

Sintasan rata-rata menunjukkan ikan nila lokal memiliki sintasan paling rendah dan berbeda nyata dengan ketiga populasi lainnya $(P<0,01)$. Pengamatan terhadap rasio kelamin jantan dan betina pada populasi yang diamati 


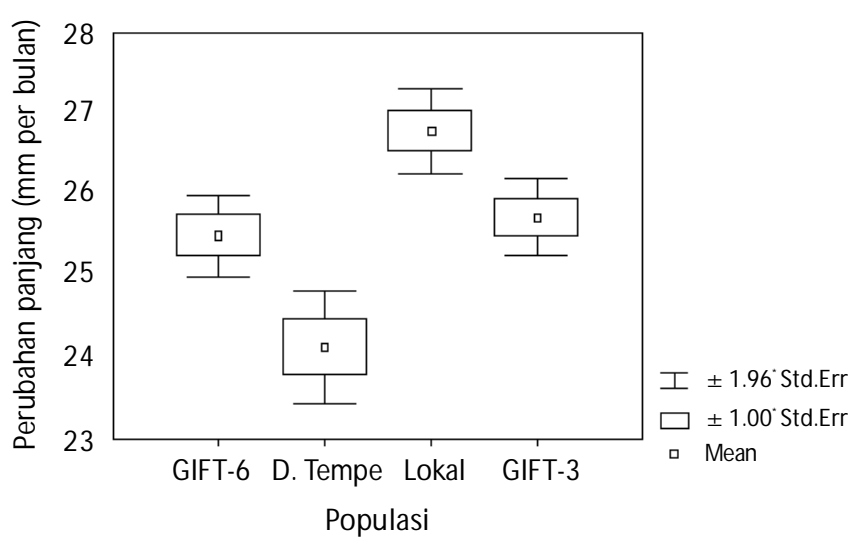

Gambar 6. Box plot perubahan panjang empat populasi ikan nila di Instalasi Plasma Nutfah Cijeruk (Gustiano et al., 2005)

berkisar antara 1,6 sampai 2. Berdasarkan data rasio jantan dan betina pada empat populasi yang diamati, tampak bahwa rasio antara jantan dan betina pada populasi yang digunakan dalam penelitian ini belum berpengaruh terhadap pertumbuhan. Data yang ada memperlihatkan meskipun populasi ikan nila Danau Tempe memiliki persentase jantan terbanyak namun tidak menunjukkan keragaan pertumbuhan yang lebih baik. Kondisi ini dikarenakan usia kematangan gonad belum dicapai untuk mempengaruhi pertumbuhan antara jenis jantan dan betina. Dari hasil yang didapat dalam penelitian, populasi terbaik yang mana dapat dijadikan kandidat dalam program pemuliaan/seleksi.

\section{Seleksi famili}

Data pembentukan famili generasi ketiga (G3) diperlihatkan pada Tabel 1 mencakup informasi induk yang digunakan, waktu pemijahan, dan jumlah larva yang dihasilkan. Sedangkan sarana yang digunakan dalam pembentukkan famili terlihat pada Gambar 7. Berdasarkan rataan pertambahan panjang dan bobot (Tabel 2), nampak bahwa rata-rata "coeficient variation" (CV) pada ikan

Tabel 1. Data pemijahan dari famili nila generasi ketiga (G3)

\begin{tabular}{|c|c|c|c|c|c|c|c|c|c|}
\hline \multicolumn{3}{|c|}{ Induk jantan } & \multicolumn{3}{|c|}{ Induk betina } & \multirow{2}{*}{$\begin{array}{c}\text { Tanggal } \\
\text { pijah }\end{array}$} & \multirow{2}{*}{$\begin{array}{l}\text { Kode } \\
\text { famili }\end{array}$} & \multirow{2}{*}{$\begin{array}{l}\text { No. } \\
\text { Jaring }\end{array}$} & \multirow{2}{*}{$\begin{array}{l}\text { Jumlah } \\
\text { benih } \\
\text { (ekor) }\end{array}$} \\
\hline No. Tag & $\begin{array}{c}\text { Bobot } \\
\text { (g) }\end{array}$ & $\begin{array}{c}\text { Panjang } \\
\text { (cm) }\end{array}$ & No. Tag & $\begin{array}{c}\text { Bobot } \\
\text { (g) }\end{array}$ & $\begin{array}{c}\text { Panjang } \\
\text { (cm) }\end{array}$ & & & & \\
\hline G2.1.0015 & 317,0 & 21,5 & $\begin{array}{l}\text { G2.2.0339 } \\
\text { G2.2.0301 }\end{array}$ & $\begin{array}{l}178,9 \\
182,4\end{array}$ & $\begin{array}{l}17,0 \\
17,3\end{array}$ & $\begin{array}{l}09 / 12 / 2006 \\
21 / 12 / 2006\end{array}$ & $\begin{array}{l}\text { G3017 } \\
\text { G3018 }\end{array}$ & $\begin{array}{c}10 \\
24,25,32\end{array}$ & $\begin{array}{l}458 \\
870\end{array}$ \\
\hline G2.1.0045 & 319,0 & 21,1 & $\begin{array}{l}\text { G2.2.1137 } \\
\text { G2.2.1105 }\end{array}$ & $\begin{array}{l}292,0 \\
280,9\end{array}$ & $\begin{array}{l}20,0 \\
18,7\end{array}$ & $\begin{array}{l}09 / 12 / 2006 \\
09 / 12 / 2006\end{array}$ & $\begin{array}{l}\text { G3001 } \\
\text { G3004 }\end{array}$ & $\begin{array}{l}17 \\
2\end{array}$ & $\begin{array}{l}453 \\
871\end{array}$ \\
\hline G2.1.0338 & 312,3 & 20,3 & $\begin{array}{l}\text { G2.2.2107 } \\
\text { G2.2.2150 } \\
\text { G2.2.2135 }\end{array}$ & $\begin{array}{l}138,4 \\
137,3 \\
140,3\end{array}$ & $\begin{array}{l}15,7 \\
15,7 \\
15,5\end{array}$ & $\begin{array}{l}09 / 12 / 2006 \\
09 / 12 / 2006 \\
09 / 12 / 2006\end{array}$ & $\begin{array}{l}\text { G3009 } \\
\text { G3012 } \\
\text { G3010 }\end{array}$ & $\begin{array}{c}11 \\
8 \\
9\end{array}$ & $\begin{array}{l}446 \\
385 \\
754\end{array}$ \\
\hline G2.1.0922 & 399,3 & 22,4 & $\begin{array}{l}\text { G2.2.0621 } \\
\text { G2.2.0609 } \\
\text { G2.2.0631 } \\
\text { G2.2.2139 } \\
\text { G2.2.0444 }\end{array}$ & $\begin{array}{l}237,5 \\
125,3 \\
173,7 \\
106,1 \\
104,7\end{array}$ & $\begin{array}{l}18,6 \\
15,2 \\
16,4 \\
14,3 \\
14,3\end{array}$ & $\begin{array}{l}09 / 12 / 2006 \\
09 / 12 / 2006 \\
09 / 12 / 2006 \\
09 / 12 / 2006 \\
21 / 12 / 2006\end{array}$ & $\begin{array}{l}\text { G3005 } \\
\text { G3008 } \\
\text { G3007 } \\
\text { G3006 } \\
\text { G3019 }\end{array}$ & $\begin{array}{c}1 \\
4 \\
3 \\
18 \\
26,31\end{array}$ & $\begin{array}{c}150 \\
339 \\
46 \\
413 \\
820\end{array}$ \\
\hline G2.1.0916 & 381,7 & 21,0 & $\mathrm{G} 2.2 .0311$ & 168,8 & 17,2 & $09 / 12 / 2006$ & G3002 & 5 & 530 \\
\hline G2.1.0529 & 366,3 & 21,6 & $\begin{array}{l}\text { G2.2.1102 } \\
\text { G2.2.1109 }\end{array}$ & $\begin{array}{l}221,2 \\
232,1\end{array}$ & $\begin{array}{l}17,6 \\
18,6\end{array}$ & $\begin{array}{l}09 / 12 / 2006 \\
09 / 12 / 2006\end{array}$ & $\begin{array}{l}\text { G3013 } \\
\text { G3015 }\end{array}$ & $\begin{array}{l}19 \\
12\end{array}$ & $\begin{array}{c}411 \\
12\end{array}$ \\
\hline G2.1.0515 & 307,8 & 20,1 & G2.2.1234 & 196,3 & 16,9 & $09 / 12 / 2006$ & G3014 & 6 & 405 \\
\hline G2.1.2105 & 268,7 & 20,0 & $\begin{array}{l}\text { G2.2.0845 } \\
\text { G2.2.0642 } \\
\text { G2.2.0821 }\end{array}$ & $\begin{array}{l}108,3 \\
192,7 \\
126,8\end{array}$ & $\begin{array}{l}14,7 \\
17,5 \\
15,2\end{array}$ & $\begin{array}{l}09 / 12 / 2006 \\
21 / 12 / 2006 \\
21 / 12 / 2006\end{array}$ & $\begin{array}{l}\text { G3011 } \\
\text { G3020 } \\
\text { G3021 }\end{array}$ & $\begin{array}{l}20 \\
15 \\
14\end{array}$ & $\begin{array}{l}270 \\
443 \\
915\end{array}$ \\
\hline G2.1.1135 & 336,2 & 20,7 & $\begin{array}{l}\text { G2.2.1307 } \\
\text { G2.2.1324 }\end{array}$ & $\begin{array}{l}142,6 \\
108,4\end{array}$ & $\begin{array}{l}15,7 \\
15,2\end{array}$ & $\begin{array}{l}09 / 12 / 2006 \\
09 / 12 / 2006\end{array}$ & $\begin{array}{l}\text { G3016 } \\
\text { G3003 }\end{array}$ & $\begin{array}{c}21 \\
7\end{array}$ & $\begin{array}{l}60 \\
90\end{array}$ \\
\hline G2.1.1148 & 357,5 & 20,2 & $\begin{array}{l}\text { G2.2.0902 } \\
\text { G2.2.0905 } \\
\text { G2.2.0946 } \\
\text { G2.2.2109 }\end{array}$ & $\begin{array}{l}168,6 \\
258,7 \\
177,8 \\
119,1\end{array}$ & $\begin{array}{l}17,2 \\
19,9 \\
17,4 \\
14,6\end{array}$ & $\begin{array}{l}21 / 12 / 2006 \\
21 / 12 / 2006 \\
21 / 12 / 2006 \\
21 / 12 / 2006\end{array}$ & $\begin{array}{l}\text { G3022 } \\
\text { G3023 } \\
\text { G3024 } \\
\text { G3.025 }\end{array}$ & $\begin{array}{c}37 \\
23,33 \\
10 * \\
34\end{array}$ & $\begin{array}{l}308 \\
870 \\
276 \\
355\end{array}$ \\
\hline
\end{tabular}




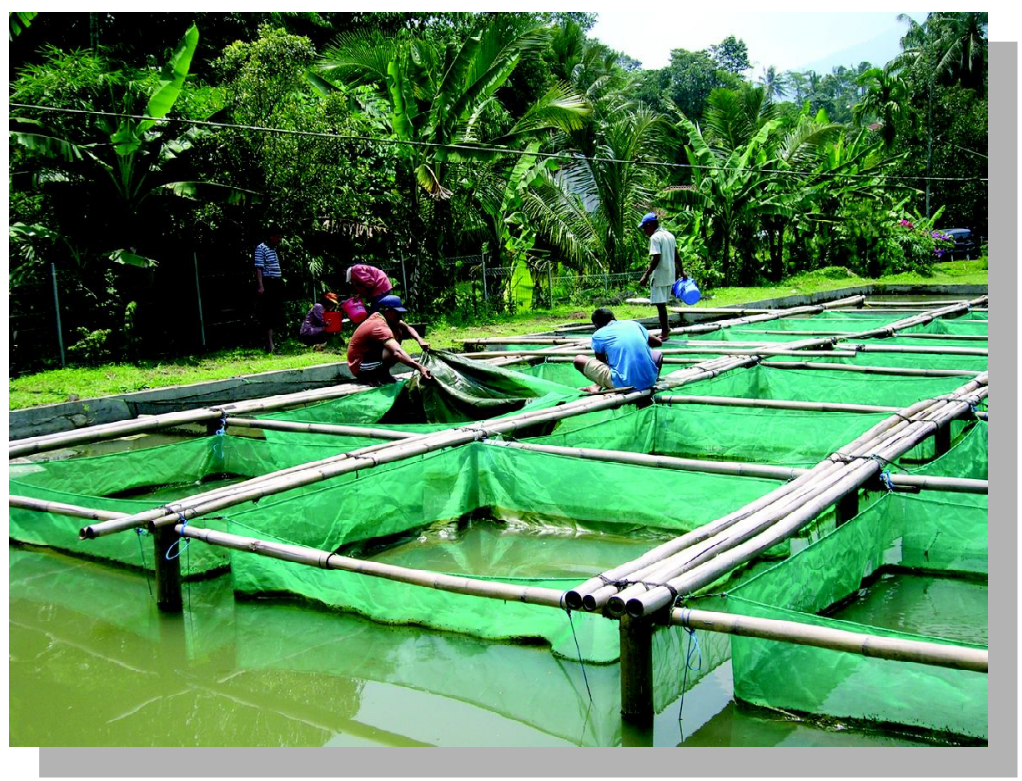

Gambar 7. Hapa tempat pemijahan untuk pembentukan famili

Tabel 2. Rataan pertambahan bobot individu pada 14 famili ikan nila setelah 5 bulan pemeliharaan

\begin{tabular}{|c|c|c|c|c|c|c|c|c|}
\hline \multirow[t]{2}{*}{ Famili } & \multicolumn{4}{|c|}{ Jantan } & \multicolumn{4}{|c|}{ Betina } \\
\hline & $\begin{array}{c}\Delta \mathrm{L} \pm \mathrm{SD} \\
(\mathrm{mm})\end{array}$ & CV & $\begin{array}{c}\Delta \mathbf{W} \pm \text { SD } \\
(\mathbf{g})\end{array}$ & CV & $\begin{array}{c}\Delta \mathrm{L} \pm \mathrm{SD} \\
(\mathrm{mm})\end{array}$ & CV & $\begin{array}{c}\Delta \mathbf{W} \pm \mathbf{S D} \\
(\mathbf{g})\end{array}$ & CV \\
\hline G3001 & $67,9 \pm 10,89$ & 16,0 & $107,0 \pm 27,26$ & 25,4 & $59,4 \pm 10,70$ & 18,0 & $87,5 \pm 23,60$ & 27,0 \\
\hline G3002 & $54,3 \pm 11,51$ & 21,2 & $75,7 \pm 28,53$ & 37,7 & $44,7 \pm 7,88$ & 17,6 & $57,2 \pm 14,58$ & 25,5 \\
\hline G3004 & $61,2 \pm 11,41$ & 18,6 & $85,5 \pm 27,62$ & 32,3 & $55,9 \pm 12,88$ & 23,0 & $77,6 \pm 24,94$ & 32,0 \\
\hline G3005 & $62,4 \pm 9,83$ & 15,8 & $106,1 \pm 22,44$ & 21,1 & $51,4 \pm 7,91$ & 15,4 & $77,9 \pm 20,94$ & 26,9 \\
\hline G3006 & $62,5 \pm 10,05$ & 16,1 & $98,2 \pm 26,16$ & 26,6 & $55,1 \pm 7,84$ & 14,2 & $79,6 \pm 16,25$ & 20,4 \\
\hline G3008 & $63,3 \pm 8,47$ & 13,4 & $93,5 \pm 20,94$ & 22,4 & $53,1 \pm 10,15$ & 19,2 & $72,1 \pm 23,23$ & 32,2 \\
\hline G3009 & $59,8 \pm 12,62$ & 21,1 & $88,4 \pm 26,00$ & 29,4 & $47,1 \pm 7,99$ & 17,0 & $58,3 \pm 15,35$ & 26,3 \\
\hline G3010 & $72,7 \pm 11,46$ & 15,8 & $109,3 \pm 26,84$ & 24,5 & $50,5 \pm 9,71$ & 19,2 & $63,4 \pm 18,82$ & 29,7 \\
\hline G3011 & $59,8 \pm 13,10$ & 21,9 & $88,9 \pm 31,96$ & 36,0 & $42,1 \pm 6,99$ & 16,6 & $49,1 \pm 13,23$ & 26,9 \\
\hline G3012 & $43,6 \pm 9,54$ & 21,8 & $60,0 \pm 18,25$ & 30,4 & $40,5 \pm 7,92$ & 19,6 & $50,4 \pm 13,76$ & 27,3 \\
\hline G3013 & $63,6 \pm 12,80$ & 20,1 & $87,7 \pm 27,26$ & 31,1 & $50,6 \pm 10,08$ & 20,0 & $60,4 \pm 16,67$ & 27,6 \\
\hline G3014 & $67,6 \pm 9,51$ & 14,1 & $115,8 \pm 32,81$ & 28,3 & $49,5 \pm 9,33$ & 18,8 & $74,4 \pm 24,50$ & 32,9 \\
\hline G3016 & $66,7 \pm 13,08$ & 19,6 & $112,3 \pm 33,00$ & 29,4 & $55,2 \pm 7,98$ & 14,4 & $82,4 \pm 17,12$ & 20,8 \\
\hline G3017 & $60,0 \pm 16,83$ & 28,0 & $79,3 \pm 30,76$ & 38,8 & $46,3 \pm 8,28$ & 17,9 & $57,0 \pm 15,57$ & 27,3 \\
\hline G3Kontrol & $60,7 \pm 6,00$ & 9,9 & $82,0 \pm 14,62$ & 17,8 & $55,1 \pm 11,71$ & 21,2 & $71,4 \pm 23,35$ & 32,7 \\
\hline
\end{tabular}

$\Delta \mathrm{L}=$ pertambahan panjang, $\Delta \mathrm{W}=$ pertambahan bobot, $\mathrm{CV}=$ coefficient of variation

jantan dari 14 famili yang diamati adalah 18,8 \pm 3,79 untuk pertambahan panjang dan 29,5 \pm 5,21 untuk pertambahan bobot. Kisaran nilai CV tersebut berada di atas CV populasi kontrol. Dengan demikian dapat dikatakan bahwa populasi ikan jantan hasil seleksi memiliki tingkat keragaman yang baik. Namun demikian, pada ikan betina nilai CV rata-rata untuk pertambahan panjang $(17,9 \pm 2,27)$ dan pertambahan bobot $(27,3 \pm$ $3,56)$ berada di bawah CV populasi kontrol untuk kedua parameter tersebut. Hal ini memberikan indikasi bahwa tingkat keragaman dari ikan betina seleksi lebih rendah dibandingkan dengan populasi kontrol. "Coefficient of variation" memberikan gambaran keragaman fenotip yang akan mendukung keberhasilan suatu program seleksi (Tave, 1993).

Pertumbuhan bobot generasi G3 populasi seleksi memperlihatkan persentase pertumbuhan bobot rata-rata $17,20 \%$ (jantan $=26,72 \%$ dan betina $=15,40 \%$ lebih besar dibandingkan dengan populasi $\mathrm{G} 3$ kontrol setelah 
pemeliharaan selama 5 bulan. Sedangkan untuk pertumbuhan rata-rata dimensi panjang populasi seleksi lebih baik sebesar $0,60 \%$ (jantan $=7,38 \%$ dan betina $=0,60 \%$ dibandingkan dengan populasi G3 kontrol.

Untuk rata-rata respon seleksi untuk bobot pada G3 adalah sebesar $17,2 \mathrm{~g}$ (jantan $=28,7 \mathrm{~g}$ dan betina $=15,4$ g) dan untuk panjang $0,4 \mathrm{~mm}$ (jantan $=28,7 \mathrm{~g}$ dan betina $=15,4 \mathrm{~g})$. Sedangkan untuk rata-rata "realized heritability" untuk bobot pada G3 adalah 0,16 (jantan = $0,14$ dan betina $=0,16)$ dan untuk panjang adalah 0,15 (jantan $=0,18$ dan betina $=0,13$ ).

Berdasarkan hasil yang diperoleh terlihat bahwa ikan seleksi menunjukkan respon genetik (genetic gain) yang cukup besar (17,20\% terhadap seleksi yang dilakukan. Penelitian sejenis pada ikan nila oleh Ponzoni et al. (2005) dilaporkan bahwa respon yang didapatkan sebesar $10,00 \%$ Dibandingkan dengan hasil yang diperoleh oleh penelitian lain, penelitian yang dilakukan menunjukkan bahwa respon seleksi yang diperoleh lebih baik.

Terlihat pula bahwa seleksi yang dilakukan memiliki nilai heretabilitas yang lebih tinggi pada individu jantan untuk parameter panjang. Sedangkan untuk bobot, heretabilitas betina lebih tinggi dibandingkan jantan. Hasil yang serupa dengan nilai heretabilitas yang lebih baik pada jantan juga terjadi pada "red tilapia" (Jarimopas, 1990) dan Oreochromis shiranus (Maluwa \& Gjerde, 2006). Nilai CV ikan betina yang rendah pada seleksi yang dilakukan dapat mengakibatkan nilai heretabilitas dan respon seleksi yang lebih kecil.

\section{Evaluasi keragaan ikan nila hasil seleksi}

Kajian benih dan larva menunjukkan karakter pertumbuhan benih nila hasil seleksi dan umur 40 hari lebih baik dibandingkan dengan generasi sebelumnya dan non seleksi yang berasal dari pembudidaya ikan (Widyastuti et al., 2008). Pada uji banding pertumbuhan antara ikan hasil seleksi dari penelitian yang dilakukan dengan ikan yang digunakan oleh pembudidaya ikan di kolam tanah didapatkan bahwa ikan hasil seleksi memiliki pertumbuhan 200\% lebih besar (Winarlin \& Gustiano, 2007). Taufik et al. (2007) juga melaporkan bahwa ikan hasil seleksi memiliki ketahananan penyakit terhadap Streptococcus lebih baik ( $140 \%$ dibandingkan dengan ikan yang digunakan oleh pembudidaya.

Hasil pengujian DNA ikan seleksi menggunakan 3 primer memperlihatkan tidak terjadi penurunan heterozygositas pada generasi kedua (heterozygositas $=0,270$; polymorphic $=84,6$ ) dibandingkan dengan generasi pertama (heterozygositas $=0,248$; polymorphic $=68,1$ ) (Nuryadi et al., 2007).
Pengujian pertumbuhan ikan hasil seleksi dibandingkan dengan beberapa strain yang telah dilepas ke masyarakat di lingkungan memperlihatkan bahwa ikan hasil seleksi memiliki pertumbuhan yang cepat dibandingkan dengan strain lainnya meskipun ikan seleksi yang digunakan memiliki ukuran awal yang lebih kecil (Listyowati \& Ariyanto, 2007). Untuk pengujian analisis proksimat, ikan hasil seleksi mempunyai kandungan protein yang tinggi dibandingkan dengan strain-strain yang diuji (Suhenda, komunikasi pribadi).

\section{KESIMPULAN}

Mengingat pentingnya ikan nila bagi budidaya air tawar di Indonesia maka dukungan pengembangan teknologi budidaya dan perbaikan mutu genetiknya untuk meningkatkan produksi dan produktivitas di masa mendatang sangat dibutuhkan.

Dengan hasil positif yang didapat pada penelitian seleksi, seleksi famili yang telah dilakukan dapat dijadikan sebagai salah satu program pemuliaan ikan nila di Indonesia untuk lingkungan dan sistem budidaya lainnya. Dapat dikemukakan bahwa respon dari suatu kegiatan seleksi yang dilakukan sangat penting untuk perbaikan kualitas.

\section{DAFTAR PUSTAKA}

Anonim. 2006. The Indonesian Aquaculture Statistics 2004. Direktorat Jenderal Perikanan Budidaya, Jakarta. $136 \mathrm{pp}$.

Anonim. 2006. Permohonan pelepasan ikan nila 'Gesit' (jantan super yy). $15 \mathrm{pp}$.

Anonim. 2006. Permohonan pelepasan varietas nila Wanayasa. $32 \mathrm{pp}$.

Arifin, 0.Z., T. Kurniasih, dan E. Nugroho. 2004. Produksi ikan nila jantan super homogametik (YY) pada ikan nila (Oreochromis niloticus). J. Pen. Perik. Indonesia 10: 79-82.

Ariyanto, D. dan Imron. 2002. Keragaan TRUSS morphometri ikan nila (Oreochromis niloticus) strain 69; GIFT G-3, dan GIFT G-6. J. Pen. Perik. Indonesia. 8: $11-18$.

Beaumont, A.R. and K. Hoare. 2003. Biotechnology and genetics in fisheries and aquaculture. Blackwell Sci. Ltd. $158 \mathrm{pp}$.

Brzesky, V.J. and R.W. Doyle. 1988. A morphometric criterion for sex discrimination in tilapia. In R.S.V. Pullin, T. Bukaswan, K. Tonguthai and J.L. Maclan (Eds.) The second ISTA, Bangkok, Thailand. ICLARM Conf. Proc. 15: 439- 444.

De Silva, S.S., T.T.T. Nguyen, N.W. Berry, and U.P. 
Amarasinghe. 2006. An evaluation of the role and impact of allient finfish in Asian inland aquaculture. Aquaculture Research. 37: 1- 17.

Dunham, R.A., K. Majumdar, E. Halerman, D. Bartley, G. Mair, G. Hulata, M. Gupta, Z. Liu, N. Pongthana, J. Bakos, D. Penman. 2001. Review of the status of aquculture genetic. Aquaculture in third millennium. NACA, DOF Thailand and FAO. p. 137- 166.

Falconer, D.S. 1989. Introduction to quantitative genetics. Longman Group Ltd, UK. 438 pp.

Fish Farming International. 2005. Tilapia set to be 'next big thing'. June 2005. p. 32-33.

Fish Farming International. 2006. Belgium to grow Tilapia. January 2006. 6 pp.

Gjedrem, T. 2005. Selection and breeding programs in aquaculture. AKVAFORSk, Institute of Aquaculture Research As. Springer Dordrecht, Netherland. 364 pp.

Gustiano, R., T. Kurniasih, dan 0.Z. Arifin. 2005. Evaluasi pertumbuhan empat populasi ikan nila (Oreochromis niloticus) di kolam percobaan Cijeruk, Bogor. Biosfera. 22: $129-133$.

Gustiano, R., J. Subagja, dan T.H. Prihadi. 2006. Pengaruh ikan introduksi terhadap keragaan ikan lokal: Studi kasus budidaya Bawal dan Patin Bangkok. Dalam Analisis kebijakan pembangunan perikanan budidaya (Editors: A. Sudradjat et al.). Pusat Riset Perikanan Budidaya, DKP. p. 145- 155.

Gustiano, R. 2007. Perbaikan mutu genetik ikan nila. Dalam kumpulan makalah bidang riset perikanan budidaya, Simposium kelautan dan perikanan. Jakarta. $6 \mathrm{pp}$.

Jangkaru, Z., M. Sulhi, dan S. Asih. 1988. Pembesaran ikan secara tunggal kelamin dan campur kelamin di kolam tanah. Bull. Penel. Perik. Darat. 7: 5-60.

Jangkaru, Z., M. Sulhi, dan S. Asih. 1992. Uji banding pertumbuhan ikan nila merah jantan dan hitam jantan dipelihara dalam kolam secara intensif. In Supriyadi et al. (Eds). Prosiding Seminar Hasil Penelitian Perikanan Air Tawar 1991/1992, Balitkanwar, Sukamandi. p. 68- 72.

Jarimopas, P. 1990. Realized response of Thai red tilapia to weight of 5 generation of size-specific selection for growth. In the second Asian Fisheries Forum. Asian Fisheries Society, Manila, Phillippines. p. 519522.

Kapusckinski, A.R. and L.D. Jacobson. 1987. Genetic guidelines for fisheries management. Univ. of Minnesota, USA. 66 pp.

Kirpichnikov, V.S. 1981. Genetic bases of fish selection. Springer-Verlag, Berlin, Heidelberg, Germany. 410 pp.
Listyowati, N. dan D. Ariyanto. 2007. Evaluasi pertumbuhan beberapa strain ikan nila pada lingkungan budidaya bersalinitas. Laporan Akhir Hasil Penelitian 2007. Loka Riset Pemuliaan dan Teknologi Budidaya Perikanan Air Tawar. 7 pp.

Mair, G.C., J.S Abucay, J.A. Beardmore and D.O.F. Skibinski. 1995. Growth performance trials of genetically ma,le (GMT) derived from ' $Y Y$ ' male in Oreochromis niloticus on station comparisons with mixed sex and sex reversed male population. Aquaculture. 137: 149160.

Maluwa, A.O. and B. Gjerde, 2006. Genetic parameters and genotype by environment interaction for body weight of Oreochromis shiranus. Aquaculture. 259: 47-55.

Martinez, R., A. Arenal, and M.P. Estrada. 1999. Mendelian transmission, transgene dosage and growth phenotype in transgenic tilapia (Oreochromis hornorum) showing ectopic expression of homologous growth hormone. Aquaculture. 173: 271- 283.

Matricia, T., A.J. Talbot, and R.W. Doyle. 1989. Instantaneous growth rate of tilapia genotypes in undisturbed aquaculture systems. I. "Red" and "Grey" morphs in Indonesia. Aquaculture. 77: 295- 302.

Myers, J.M., D.J. Penman, K.J. Rana, N. Bromage, S.F. Powel, and B.J. McAndrew. 1995. Application of induced androgenesis with Tilapia. Aquaculture. 137: 137- 160 .

Nugroho, E., A. Widiyati, dan T. Kadarini. 2002. Keragaan genetik ikan nila GIFT berdasarkan polimorfisme mitokondria DNA d-loop. J. Pen. Perik. Indonesia. 8: $1-6$.

Ponzoni, W.R., A. Hamzah, S. Tan, and N. Kamaruzzaman. 2005. Genetic parameters and response to selection for live weight in GIFT strain of nile tilapia (Oreochromis niloticus). Aquaculture. 247: 203-210.

Rahman, M.A. and N. MacClean. 1999. Growth performance of transgenic tilapia containing an exogenous piscine growth hormone gene. Aquaculture. 173: 333-346.

Scott, A.G., D.J. Penman, J.A. Beardmore, and D.O.F. Skibinski. 1989. The 'yy' supermale in Oreochromis niloticus and its potential in aquaculture. Aquaculture. 78: $237-251$.

Subagyo, Sularto, A. Hardjamulia, F. Sukadi, dan W. Ismail. 1993. Penelitian pembesaran ikan nila tunggal kelamin di jaring apung. Bull. Pen. Perik. Edisi Khusus. 5: 3851.

Sugama, K. 2006. Perbaikan mutu genetik ikan untuk mendukung pengembangan perikanan budidaya. Orasi 
pengukuhan professor riset, bidang perikanan budidaya, Badan Riset Kelautan dan Perikanan, Departemen Kelautan dan Perikanan. 77 pp.

Sumantadinata, K. dan J. Subardja. 1979. Hibridisasi antara ikan nila dan ikan mujair. Pewarta LPPD. 2: 31- 34.

Suseno, D. 1983. Pertumbuhan penelitian pertumbuhan ikan mujair (Tilapia mosambica) dan nila (Tilapia nilotica) Bull. Penel. Perik. Darat. 4: 27-34.

Taufik, P., D. Sugiani, U. Purwasih, dan R. Gustiano. 2008. Uji ketahanan penyakit Streptococcosis dan lingkungan pada ikan nila (Oreochromis niloticus) seleksi dan non seleksi. 8 pp. (dalam proses publikasi).

Tave, D. 1993. Genetics for fish managers. The AVI Publ. Comp. Inc. NY, USA. 418 pp.

Tave, D. 1995. Selective breeding programmes for medium-sized fish farm. FAO Fish. Tech. Pap. 352: $1-122$.

Wakhid, A dan Suwarsito. 2003. Uji kekebalan ikan nila strain GIFT dan Chitralada. Sains Akuatik. 6: 96- 100.

Wardoyo, S.E. 2005. Pengembangan budidaya ikan nila

(Oreochromis niloticus) di Indonesia. Orasi pengukuhan ahli peneliti utama bidang budidaya perikanan. Departemen Kelautan dan Perikanan. 49 pp.

Widiyati, A., Sudarto, L. Emmawati, dan T. Kadarini. 1996. Evaluasi pertumbuhan beberapa strain ikan nila (Oreochromis niloticus). In A. Sarnita, et al. (Eds.). Prosiding Hasil Penelitian Perikanan Air Tawar 1994/1995, Balitkanwar, Sukamandi. p. 44-49.
Widiyati, A. 2003. Keragaan fenotipa dan genotipa ikan nila (Oreochromis niloticus) dari Danau Tempe dan beberapa sentra produksi di Jawa Barat. Tesis Magister Sains. IPB. 41 pp.

Widiyati, A., O.Z. Arifin, E. Setiadi, Winarlin, dan R. Gustiano. 2005. Implementasi hasil litbang pada demplot ikan nila (Orechromis niloticus) melalui budidaya monosex pada lingkungan yang optimal. Kementerian Riset dan Teknologi. 39 pp.

Widiyati, A., R. Gustiano, dan 0.Z. Arifin. 2006. Uji pertumbuhan 24 famili generasi pertama ikan nila di karamba jaring apung. Sainteks. 13: 210-216.

Widyastuti, Y.R, J. Subagja, dan R. Gustiano. 2008. Bioreproduksi ikan nila (Orechromis niloticus) seleksi dan non seleksi: karakter induk, telur dan embrio dan benih. 9 pp. (dalam proses publikasi)

Winarlin dan R. Gustiano. 2008. Uji banding pertumbuhan biomassa ikan nila (Oreochromis niloticus) seleksi dan non seleksi di kolam dan di danau. 7 pp. (dalam proses publikasi)

Yunus, M., Rusmaedi, dan A. Widiyati. 1987. Budidaya ikan nila hibrida. Bull. Penel. Perik. Darat. 6: 27-31.

Zairin, J. 2003. Endrikronologi dan peranannya dalam perikanan Indonesia di masa depan. Paper orasi guru besar tetap ilmu endikronologi dan fisiologi hewan air IPB, Bogor. 70 pp. 